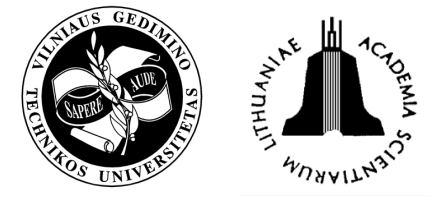

\title{
PRESUMPTIONS OF EFFECTIVE OPERATION OF DIESEL ENGINES RUNNING ON RME BIODIESEL. RESEARCH ON KINETICS OF COMBUSTION OF RME BIODIESEL
}

\author{
Sergejus Lebedevas ${ }^{1}$, Andrius Vaicekauskas ${ }^{2}$, Pavel Suškov ${ }^{1}$ \\ Dept of Marine Engineering of Maritime Insitute of Klaipéda University, \\ I. Kanto g. 7, LT-92123 Klaipéda, Lithuania.E-mails: ${ }^{1}$ laivum@ji.ku.lt; ${ }^{2}$ andrius@swelbalt.lt
}

Received 5 December 2006; accepted 1 February 2007

\begin{abstract}
The results of experimental research on kinetics of fuel combustion of diesel engine A41are presented in the publication. The change of characteristics of indicated work (in-cylinder pressure and temperature, period of induction, heat release and heat release rate) and fuel injection (fuel injection pressure, fuel injection phases) was determined in diesel engine running on RME biodiesel being compared to diesel fuel. The results of researches were used to explain experimentally determined changes of operational and ecological characteristics of diesel engine running on RME biodiesel. In addition, the reliability of diesel engine A41 running on RME biodiesel was evaluated. The presumptions of effective operation of diesel engines running on RME biodiesel were formulated.
\end{abstract}

Keywords: kinetics of combustion, heat release, fuel injection, reliability of diesel engine, biodiesel.

\section{Introduction}

Publication continues the presentation of results of common researches of Lithuanian Agricultural University and Klaipeda University into production and adaptation of biodiesel in fleets of diesel engines of Lithuania. Researches are conducted under the auspices of Council of science and studies of Lithuania and performed under the framework of international project "EUREKA. BIOWASTEFUEL.E!3234". The results of researches on chemical, physical and motor properties of various biodiesels, as well as on the change of operational and ecological characteristics of diesel engine running on biodiesel were presented in previous publications. The results of research on kinetics of combustion and fuel injection of diesel engine A41 are presented in this publication. The presumptions of effective operation of diesel engines running on RME biodiesel are formulated on the basis of the obtained results of researches. Experimental researches were performed together with Altaj State Technical University (Russian Federation).

Nowadays the researches on biodiesel fuel are directed to reduction of cost price [1] and improvement of low temperature characteristics. The usage of waste vegetable oils and animal fats for the production of biodiesel is one of the promising ways to reduce the cost price of biodiesel. The improvement of low temperature characteristics is solved by applying fuel additives. As a result, the multicomponental biodiesel fuels are created. The base of new types of biodiesels consists of traditional types of biodiesel: rapeseed methyl ester - RME, soybean methyl ester - SME, palm-oil methyl ester - PME. The new biocomponents change properties of biodiesel and influence differently the work process of diesel engine which forms the main technical-economical and ecological parameters. The comparative research on characteristics of indicated work of diesel engine forms the base to choose the proportions of biocomponents of new biodiesels, which practically realises the engineering of fuel. It also allows to evaluate the optimum and critical values of parameters of biodiesel and to take compromise decisions regarding optimisation of regulation parameters of diesel engine.

The goal of the performed research was to evaluate the change of parameters of fuel injection and kinetics of fuel combustion of diesel engine A41 running on RME biodiesel. The results of research will be used to prove the observed changes of operational and ecological parameters, to evaluate the change of reliability of diesel engine and formulate the presumptions of effective operation of diesel engines running on RME biodiesel.

\section{Materials and methods}

The object of the research is chosen in respect of the structure of diesel engines park of Agricultural machines of Lithuania (see Fig 1) and technical characteristics of mostly spread models of diesel engines.

Such choice enssures the possibility of practical application of obtained results of the research. The object of the research is the section of one cylinder of tractor purpose diesel engine A41 (producer JSC "Altaiskij motornij zavod", Russian Federation). 
Diesel engine A41 is characterised by similar technical and constructive parameters, presented in Table 1 .

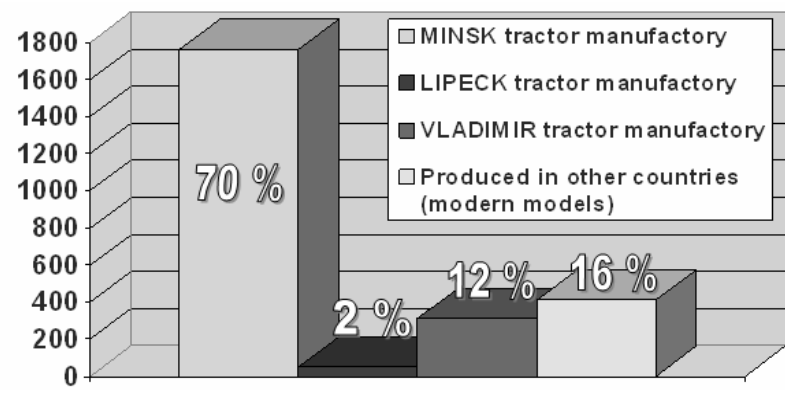

Fig 1. Statistical data of registered new tractors with diesel engines in Lithuania per year 2003

Table 1. Parameters of researched diesel engine

\begin{tabular}{|c|l|c|}
\hline No & Parameter & $1 \mathrm{~A} 41$ \\
\hline 1 & Cylinder diameter $D, \mathrm{~m}$ & 0,13 \\
\hline 2 & Piston stroke length $S, \mathrm{~m}$ & 0,14 \\
\hline 3 & Engine displacement $V_{\mathrm{h}}, \mathrm{dm}^{3}$ & 1,86 \\
\hline 4 & Compression ratio $\varepsilon$ & 16 \\
\hline 5 & Rated output $P_{e}, \mathrm{~kW}$ & 14 \\
\hline 6 & $\begin{array}{l}\text { Rated break mean effective pres- } \\
\text { sure } p_{m e}, \mathrm{MPa}\end{array}$ & 0,85 \\
\hline 7 & Rated speed $n, \mathrm{rpm}$ & 1750 \\
\hline 8 & Parameters of fuel injector & $4 \times 0,25 \times 150^{\circ}$ \\
\hline 9 & Fuel injection & direct \\
\hline 10 & Type of combustion chamber & open \\
\hline
\end{tabular}

Tested types of fuel: summer diesel fuel according to standard GOST 305, biodiesel RME, certified according to standard LST EN 14214, produced in JSC "Rapsoila" (Mažeikiai, Lithuania), RME blends with mineral diesel fuel by volummetric proportions $90 / 10$ (B10), 85/15 (B15) and 70/30 (B30).

The main physical-chemical and motor parameters of tested fuels are presented in Table 2.

Table 2. Main physical-chemical parameters of tested fuels

\begin{tabular}{|c|c|c|c|c|c|c|}
\hline \multirow[b]{2}{*}{ No } & \multirow[b]{2}{*}{ Characteristic } & \multicolumn{5}{|c|}{ Fuel } \\
\hline & & $\begin{array}{c}\text { Diesel } \\
\text { fuel }\end{array}$ & RME & B10 & B15 & B30 \\
\hline 1 & $\begin{array}{l}\text { Density at } 20^{\circ} \mathrm{C}, \\
\mathrm{g} / \mathrm{cm}^{3}\end{array}$ & 0,840 & 0,887 & 0,845 & 0,847 & 0,854 \\
\hline 2 & $\begin{array}{l}\text { Viscosity at } \\
40^{\circ} \mathrm{C} \text {, stc }\end{array}$ & 2,6 & 4,83 & 3,0 & 3,2 & 3,8 \\
\hline 3 & Cetan number & 46 & 51,6 & 51,04 & 50,76 & 49,92 \\
\hline 4 & $\begin{array}{l}\text { Heating value } \\
H_{u}, \mathrm{~kJ} / \mathrm{kg}\end{array}$ & 42470 & 37417 & 41965 & 41707 & 40954 \\
\hline 5 & $\begin{array}{l}\text { Stoichiometric } \\
\text { ratio } L_{0}\end{array}$ & 0,495 & 0,433 & 0,489 & 0,485 & 0,476 \\
\hline 6 & $\begin{array}{l}\text { Chemical } \\
\text { composition }\end{array}$ & & & & & \\
\hline & $C, \%$ & 87,0 & 77,0 & 86,0 & 85,5 & 84,0 \\
\hline & $H, \%$ & 12,6 & 12,1 & 12,55 & 12,52 & 12,45 \\
\hline & $0, \%$ & 0,4 & 10,9 & 1,45 & 1,98 & 3,55 \\
\hline
\end{tabular}

The parameters of high pressure fuel injection system and indicated process were measured by piezo sensors. The in-cyliner pressure $P_{g}$, fuel injection pressure $P_{f}$, the start of fuel injection phase $\varphi_{f 1}$ and the end $\varphi_{f 2}$ were measured. The error of measurement of pressures $P_{g}$ and $P_{f}$ is $\pm 0,5 \%$. The error of measurement of fuel injection phases $\left(\varphi_{f 1}\right.$ and $\left.\varphi_{f 2}\right)$ and characteristic angles of cranckshaft is $\pm 0,5^{\circ} \mathrm{CA}$. The signals of sensors were transferred by 20 channels into registration station of high-speed processes $\mathrm{H}-2000$. The received signals were treated and collected by program complex "ACTest". The mathematical modelling of temperature of gases and characteristics of heat release were performed by applying the program complex "Cycle". The main aspects of research on indicated process and fuel injection process are shown in Fig 2.

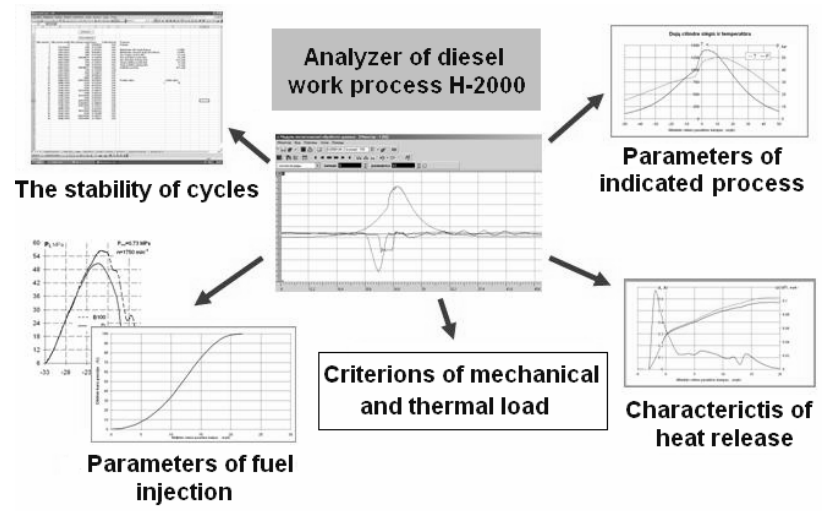

Fig 2.The aspects of research on work process and characteristics of fuel injection of diesel engine A41

The properties of heat release have influence on power, fuel consumption, reliability, the level of sound, vibration and harmful emission of exhaust gases of diesel engine. The process of formation of fuel - air mixture has primary influence on heat release. This process depends on dynamic state of air charge and fuel injection properties. Because of that the research on kinetics of combustion is related with research on characteristics of fuel injection.

$\mathrm{XK}$ and XA types of thermocouple are used for measurement of the temperature of cooling liquid, lubricating oil and exhaust gases of diesel engine. The relative error of measurement of temperature is $\pm 1 \%$. Fuel consumption is measured with automated device АБР-50. The relative error of measurement of fuel consumption is $\pm 0,5 \%$.

The algorithm for calculation of characteristics of heat release $\mathrm{X}=f(\varphi)$ and $d \mathrm{X} / d \varphi=f(\varphi)$ is based on differencial equation of first law of thermodynamics:

$$
\begin{aligned}
& \left(c_{v}{ }^{\prime} G^{\prime}+c_{v}{ }^{\prime \prime} G^{\prime \prime}\right) \frac{d T}{d \varphi}=\left[H_{u}-0,7 T+182\right] \times \\
& q_{c i k l} \frac{d X}{d \varphi}+\frac{d Q_{w}}{d \varphi}-K_{4} P_{B},
\end{aligned}
$$

where $p$ and $T$ - in-cylinder pressure and temperature; $G^{\prime}$ and $G^{\prime \prime}$ - masses of air and products of complete combustion; $c_{v}{ }^{\prime}$ ir $c_{v}{ }^{\prime \prime}$ - isochoric specific heat capacity 
of air and products of complete combustion; $q_{\text {cycle }}-$ the portion of fuel injected during one cycle; $Q_{w}$ - heat losses through cylinder liner into cooling system, which can be alternatively calculated by methodics of G. Woschni [2] or Central Institute of Diesel Reseach (St. Peterburg, Russian Federation) [3]; X - coefficient of heat release; $\mathrm{K}_{4}-$ constant; $\mathrm{P}_{\mathrm{B}}-$ trigonometric function.

The possibility to enter the chemical composition of a wide range of fuels is realised by the mathematical model. The following chemical elements can be entered: coal $-\mathrm{C}$, hydrogen $-\mathrm{H}_{2}$, oxygen $-\mathrm{O}_{2}$, water $\mathrm{H}_{2} \mathrm{O}$, sulphur $-\mathrm{S}$. The chemical composition of fuel oxidator (air) is entered by the following components: $\mathrm{O}_{2}$, nitrogen $-\mathrm{N}_{2}$, carbon dioxide $-\mathrm{CO}_{2}, \mathrm{H}_{2} \mathrm{O}$ and argon $A_{r}$. The values of internal energy and specific heat capacity of air and products of complete combustion are calculated by empyrical extrapolational polynomial equation of the third degree [4]:

$$
U^{\prime}, U^{\prime \prime}, c^{\prime}, c^{\prime \prime}=A_{0}+A_{1} T+A_{2} T^{2}+A_{3} T,^{3}
$$

where $A_{0}, A_{1}, A_{2}, A_{3}$ - coefficients, which are calculated by third degree polynomial equations depending on temperature and mass values of air and products of complete combustion $\left(\mathrm{N}_{2}, \mathrm{CO}_{2}, \mathrm{H}_{2} \mathrm{O}, \mathrm{SO}_{2}\right.$ and $\left.\mathrm{A}_{\mathrm{r}}\right)$.

Stoichiometric ratio $L_{0}$ of the ammount of air which is theoretically required for complete combustion of fuel, is calculated depending on chemical composition of fuel by formula:

$$
L_{0}=\frac{1}{0,21}\left(\frac{C^{M}}{12}+\frac{H^{M}}{4}-\frac{S^{M}+O^{M}}{32}\right)
$$

where $C^{M}, H^{M}, O^{M}, S^{M}-$ mass portions of fuel elements, $\mathrm{kg} / \mathrm{kg}$ fuel.

The heating value $H_{U}$ is determined by formula of Mendelejev widely used in practice:

$$
\begin{aligned}
& H_{U}=\left[81 C^{M}+246 H^{M}-30\left(0^{M}-S^{M}\right)-\right. \\
& \left.6\left(W^{M}+9 H^{M}\right)\right] / 4.19,
\end{aligned}
$$

where $C^{M}, H^{M}, O^{M}, S^{M}, W^{M}-$ mass portions of fuel elements, $\mathrm{kg} / \mathrm{kg}$ fuel.

The thermal and mechanical load of parts of cylinder - liner group can be evaluated by widely used in practice indirect criterions, which is allowable in comparative research. The following indirect criterions were used:

- maximum in-cylinder pressure $p_{\max }$ : for evaluation of mechanical load;

- maximum in-cylinder temperature $T_{\max }$ and medium temperature of compression - power stroke $T_{\text {cycle }}$ : for evaluation of thermal load;

- criterions of prof. A. Kostin $q_{p}$ ir $q_{y}$ : for evaluation of the thermal load.

\section{The results of experimental researches}

\subsection{Parameters of indicated work}

The air ratio $\alpha$ is one of the main parameters which influences the work process of diesel engines especially without air turbocharging. The air ratio $\alpha$ is calculated by formula: $\alpha=G_{a i r} /\left(G_{f} \times L_{0}\right)$, where $G_{a i r}$ - air consumption per hour, $\mathrm{kg} / \mathrm{h}, G_{f}-$ fuel consumption per hour, kg/h.

The air ratio of biodiesel increases depending on lower value of stoichiometric ratio: 0,476 and $0,433-$ values of biodiesels B30 and B100 compared to value of mineral diesel fuel - 0,495. The consumption of air $G_{\text {air }}$ is consistent under equal environmental conditions and equal work regimes. In this case the air ratio depends only on fuel consumption $G_{f}$ and stoichiometric ratio $L_{0}$. The fuel consumption can be expressed by formula: $G_{f}=b_{e} P_{e}$, where $b_{e}$ - brake specific fuel consumption, $\mathrm{g} / \mathrm{kWh}, P_{e}-$ diesel engine brake power, $\mathrm{kW}$.

The air ratio becomes the function of two arguments: $b_{e}$ and $L_{0}$ at the identical diesel brake power $\left(P_{e}=\right.$ const). The biggest change of brake specific fuel consumption is determined at low loads of diesel engine running on biodiesel (see Fig 3). The higher value of air ratio of biodiesel is predetermined by different values of stoichiometric value $L_{0}$ being compared with mineral diesel fuel at low loads. This difference compensates the growth of break specific fuel consumption $b_{e}$ by increasing workload. The increase in air ratio $\alpha$ is the following for the biodiesels being compared with mineral diesel fuel: $\mathrm{B} 30 \sim 0,5 \div 0,15$ and $\mathrm{B} 100 \sim 0,75 \div 0,3$, $\alpha \approx$ idem at nominal loads.

The effectiveness of convertation of the heat of fuel combustion into indicated work is evaluated by overall efficiency factor $\eta_{i}$. It can be determined as a function of the following parameters: air ratio $\alpha$, compression ratio $\varepsilon$ and ratio $p_{\max } / p_{a}\left(p_{a}-\right.$ pressure of working fluid at the beginning of compression stroke) [5].
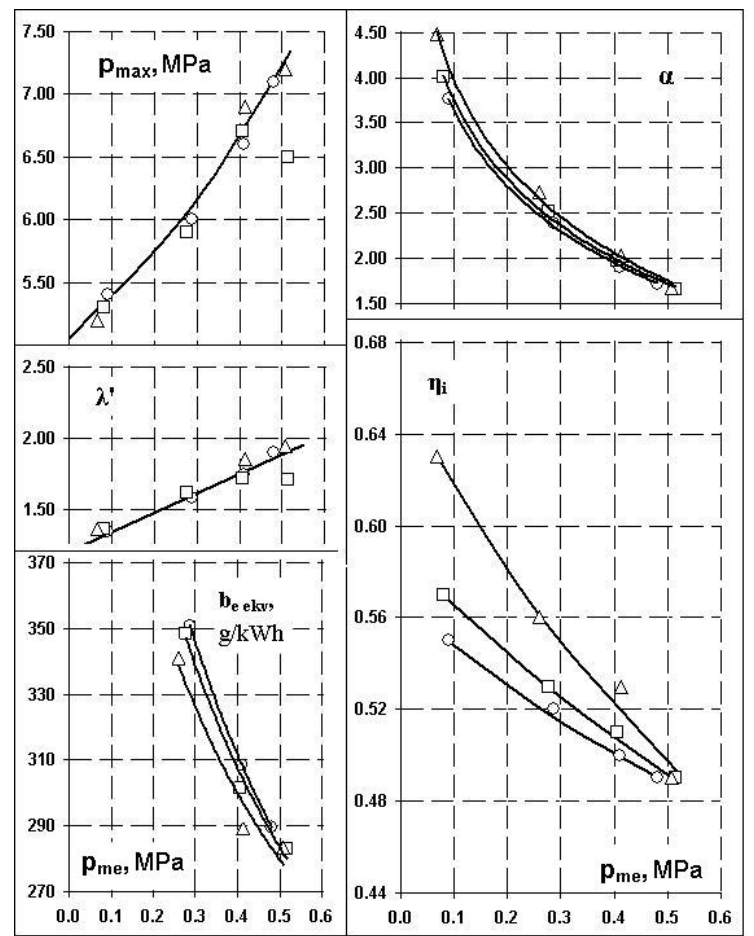

Fig 3. Parameters of work process of diesel engine A41 while running on biodiesel: $O$ - diesel fuel, $\square-$ RME biodiesel B30, $\triangle-$ RME biodiesel B100 
The indicated efficiency factor is the function of three arguments: $\alpha, \varepsilon$ and $\lambda$ (where $\lambda$-pressure ratio) regarding the dependence on theory of internal combustion engines $p_{\max }=p_{a} \varepsilon^{n_{1}} \lambda$. The number of arguments decreases down to two $\eta_{i}=f(\alpha, \lambda)$ at the constant constructive parameters of combustion chamber ( $\varepsilon=$ const $)$.

The pressure ratio $\lambda$ depends mainly on cycle quantity of fuel $q_{\text {cycle }}$ or fuel consumption per hour $G_{f}$ by constant regulation of fuel supply systems for diesels without turbocharging. The linear dependence, viz. pressure ratio $\lambda$ change can be seen depending on load of diesel engine (see Fig 3 ). The value of pressure ratio $\lambda$ differs only by $2 \div 3 \%$ for the different tested fuels at constant rated output $P_{e}\left(\lambda^{\prime}=p_{\max } / p_{c}{ }^{\prime}\right.$, where $p_{c}-$ pressure of working fluid at the start of combustion, (see Fig 3). In case of made notes the indicated efficiency factor depends exceptionally on air ratio $\alpha$.

Functions $\eta_{i}=f(\alpha)$ are presented in Fig 4. Obviously, air ratio $\alpha$ is not the universal argument for evaluation of the change of indicated efficiency factor when replacing mineral diesel fuel by biodiesel. The coefficients $a$ and $b$ of function $\eta_{i}=a+b \alpha$ are different for different types of fuel.

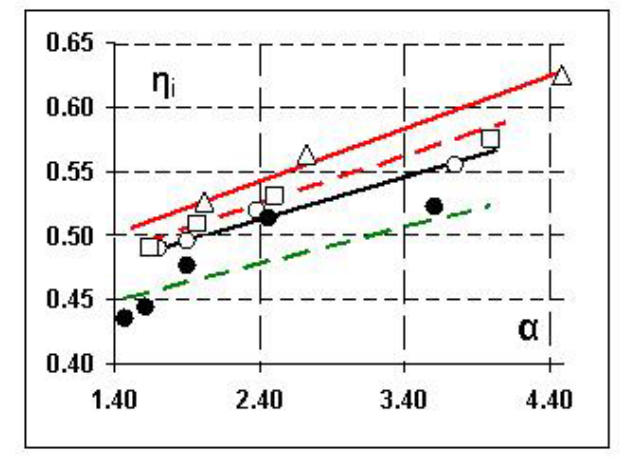

Fig, 4. Dependence of the indicated efficiency factor of function $\eta_{i}$ on air ratio $\alpha$ of diesel engine A41: $\mathrm{O}-$ diesel fuel,

$\square-$ RME biodiesel B30, $\triangle-$ RME biodiesel B100

The indicated efficiency factor can be additionally influenced by different characteristics of fuel injection and combustion depending on physical - chemical properties of fuel [6].

The multiparameter characteristics $\eta_{i}, p_{m i}=f\left(\alpha, \lambda, p_{k}, n\right)$ and mathematical models based on it should be corrected to be used in practice for biodiesel [5].

The equivalent fuel consumption $b_{e}$ ekv beside the indicated efficiency factor is used for the evaluation of fuel economy parameters: $b_{e}^{B}{ }_{e k v}=b_{e}^{B} \frac{H_{u}^{B}}{H_{u}^{D}}$ (see Fig 3) [7]. The equivalent fuel consumption experimental determination is less complicated in practice. The observed relative change of equivalent fuel consumption is similar to relative change of indicated efficiency factor when replacing mineral diesel fuel by biodiesel.

\subsection{The mechanical and thermal load of diesel engine}

The temperature of exhaust gases $T_{r}$ is a less sensitive parameter than indicated efficiency factor in case of replacing the sort of fuel. Almost identical level of the temperature of exhaust gases $T_{g}$ was determined for the following sorts of fuel: mineral diesel fuel, B30 and B100 at $P_{e}=$ idem (see Table 3).

Table 3. Temperature of exhaust gases of tested fuels

\begin{tabular}{|c|c|c|c|c|c|}
\hline \multirow{2}{*}{ No } & \multirow{2}{*}{ Fuel } & \multicolumn{4}{|c|}{$p_{m e}, \mathrm{MPa}$} \\
\cline { 3 - 6 } & & $0,07 \div 0,09$ & $0,26 \div 0,29$ & 0,41 & $0,48 \div 0,52$ \\
\hline 1 & Diesel fuel & $260{ }^{\circ} \mathrm{C}$ & $365^{\circ} \mathrm{C}$ & $450{ }^{\circ} \mathrm{C}$ & $490{ }^{\circ} \mathrm{C}$ \\
\hline 2 & B30 & $250{ }^{\circ} \mathrm{C}$ & $350^{\circ} \mathrm{C}$ & $430^{\circ} \mathrm{C}$ & $510^{\circ} \mathrm{C}$ \\
\hline 3 & B100 & $245^{\circ} \mathrm{C}$ & $340^{\circ} \mathrm{C}$ & $430^{\circ} \mathrm{C}$ & $510^{\circ} \mathrm{C}$ \\
\hline
\end{tabular}

The temperature of exhaust gases $T_{g}$ is widely used in practice as indirect criterion for evaluation of thermal load of parts of cylinder-liner group of diesel engine. The temperature of exhaust gases non-completely reflects thermal load of diesel engine because of changes of spontaneous fuel injection phases at running of diesel engine on different sorts of fuel. The following parameters are used additionally for evaluation of the change of thermal load: maximum in-cylinder temperature $T_{\max }$, medium temperature of compression - power stroke $T_{\text {cycle }}$ and criterions of prof. A. Kostin $q_{p}$ and $q_{y}$ (see Fig 5).

Obtained results show that the replacement of mineral diesel fuel with biodiesel up to concentration of B100 does not increase mechanical load of parts of cylinder-liner group of diesel engine. The identical value of maximum pressure $p_{\max }$ is obtained independently on the sort of fuel at constant rated output $P_{e}=$ idem. Experimental data curve of maximum pressure divergence from generalized curves is about $\pm 1 \div 1,5$ bar (see Fig 3 ). Criterions $q_{p}$ and $q_{y}$ are proportional to relative flow of heat near the bottom of piston and cooling system of diesel engine:

$$
\begin{aligned}
& q_{p}=2,34 c_{m}\left(\frac{D}{\eta_{v} p_{K}}\right)^{0,38}\left(p_{m e} \times b_{e} \frac{T_{K}}{T_{0}}\right)^{0,88} \\
& q_{y}=462,5 c_{m}^{0,565} \times \frac{p_{m e} b_{e} T_{K}}{D^{0,5}\left(\eta_{v} p_{K}\right)^{0,38}} .
\end{aligned}
$$

where $D$ - diameter of cylinder, $\eta_{v}$ - air ratio of filling the cylinder, $c_{m}$ - medium speed of piston, $p_{k}$ - turbocharging pressure, $T_{k}$ - temperature of turbocharging air, $T_{0}$ - environmental temperature.

After non-complicated simplifying for the diesel without turbocharging the functions of criterions $q_{p}$ and $q_{y}$ can be expressed as follows: $q_{p}=K_{1} \beta^{0,88}$, $q_{y}=K_{2} \beta^{0,5}$, where $\beta=1 / \alpha$ - ratio of usage of air fluid, reverse to air ratio $\alpha, K_{l}$ and $K_{2}$ - constants. 


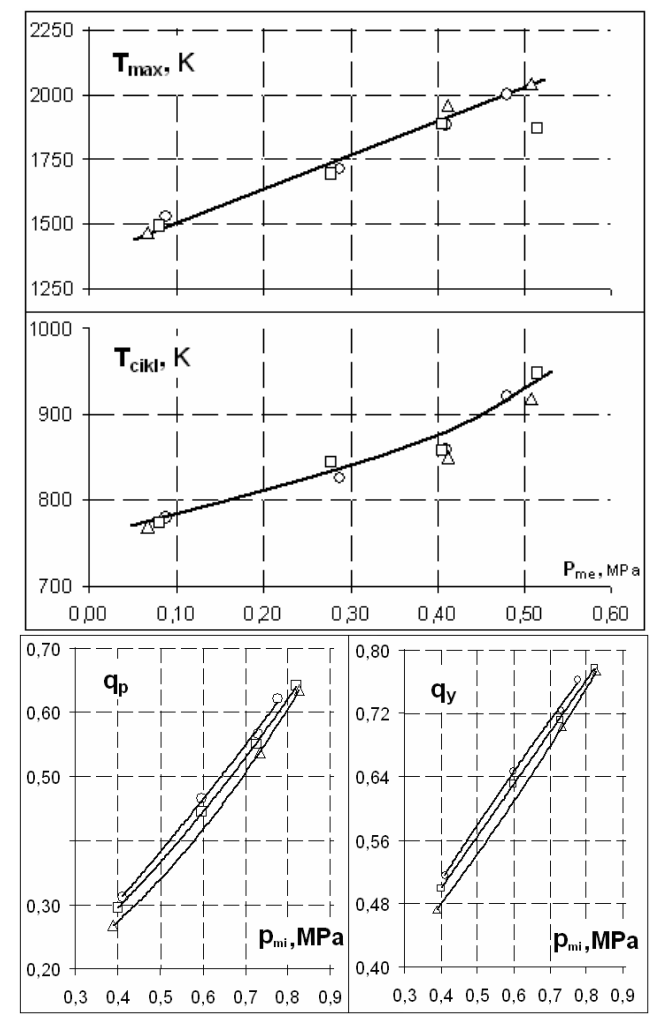

Fig 5.Criterions of thermal load of diesel engine A41 while running on biodiesel: : $O$ - diesel fuel,

$\square$ - RME biodiesel B30, $\triangle$ - RME biodiesel B100

The determined change of criterions $q_{p}$ and $q_{y}$ of different sorts of fuel depending on load (see Fig 5) confirms that replacement of mineral diesel fuel by biodiesel does not increase thermal load and heat transferring into cooling system at the same level of rated output.

\subsection{The characteristics of fuel injection}

The replacement of mineral diesel fuel by biodiesel practically does not change the phases of fuel injection $\left(\varphi_{\mathrm{f} 1}-\right.$ start of injection and $\varphi_{\mathrm{f} 2}-$ end of injection $)$ and duration of injection at the same fuel injection timing and rated output.

The charcateristic phases of biodiesel injection remain the same being compared with mineral diesel fuel (see Fig 6).

The analogous results of researches are obtained and for rapeseed oil while viscosity of it is $~ 15 \%$ higher being compared to mineral diesel fuel. The viscosity of biodiesel B100 is $~ 85 \%$ and density is $~ 5 \%$ higher being compared to mineral diesel fuel.

The replacement of mineral diesel fuel with biodiesel ensuring the same level of rated output of diesel engine is related to the increase of cycle quantity of fuel $q_{\text {cycle }}$ because of lower heat value $H_{u}$ of biodiesel. The constancy of duration of fuel injection $\varphi_{f_{i n j}}$ confirms that the intensiveness of injection or pressure of injection (speed of volume and mass injection) increases by using biodiesels. The increase of fuel pressure before fuel injector $P_{f}$ is determined within the whole researched range of loads (see Fig 7).

The higher pressure before fuel injection $P_{f}$ of biodiesels stabilizes characteristic of fuel injection. The real timing of lifting of injector needle is earlier for $1 \div 1,5^{\circ}$ CA up to dead top center (see Fig 8 ).

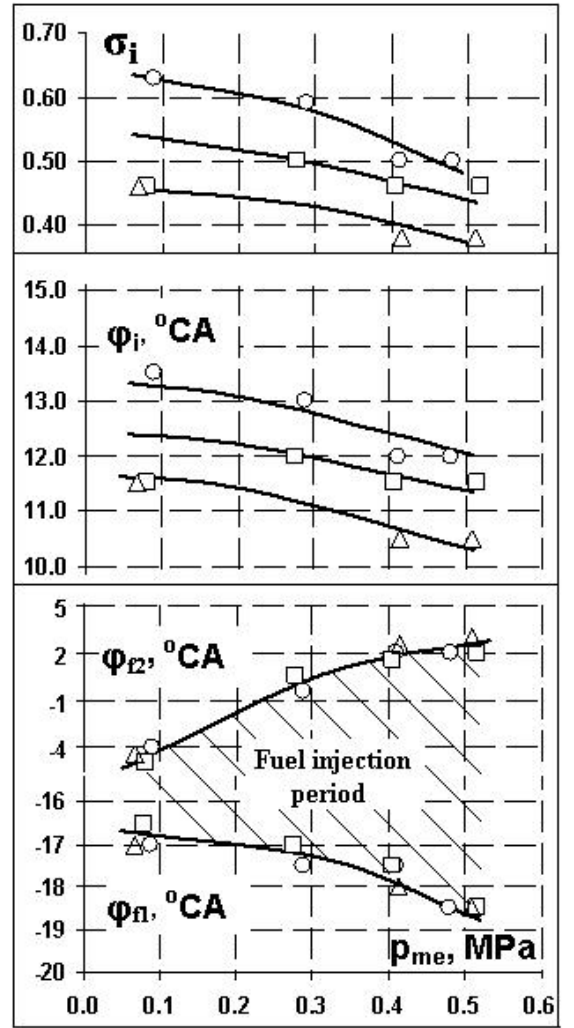

Fig 6. Phases of fuel injection of A41 while running on biodiesel: : $\mathrm{O}$ - diesel fuel, $\square-\mathrm{RME}$ biodiesel B30,

$\triangle-$ RME biodiesel B100

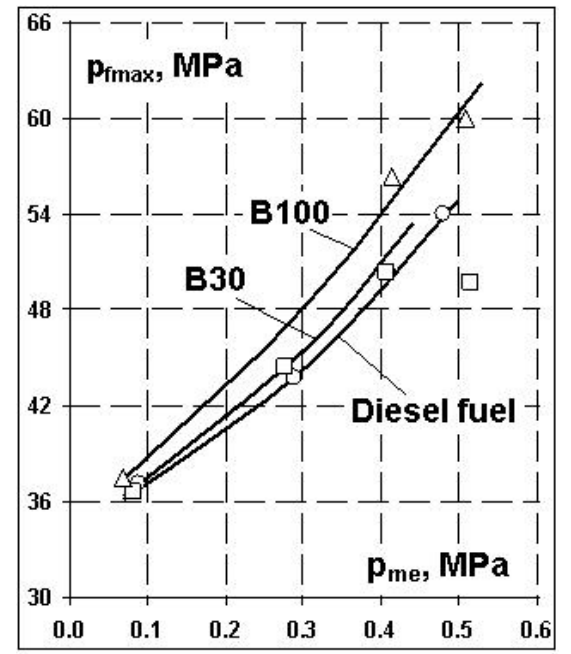

Fig 7. The change of maximum pressure before fuel injection $P_{f}$ of diesel engine A41 while running on biodiesel: $O$ - diesel fuel, $\square$ - RME biodiesel B30, $\triangle$ - RME biodiesel B100 


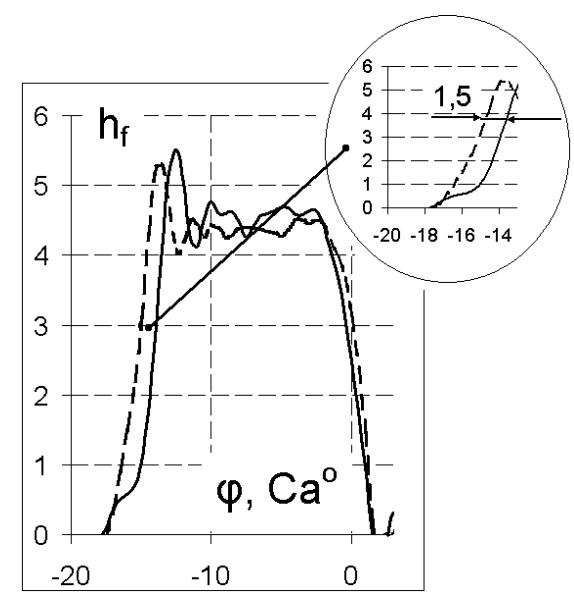

Fig 8. The characteristic of lifting of injector needle $h_{f}$ of diesel engine A41: - diesel fuel,

- - - - RME biodiesel B100

The front of characteristic of fuel pressure before fuel injection remains unchanged (see Fig 9). Is it known that the increase of profile and maximum value of $P_{f}$ together with density of fuel significantly influence the quality of fuel injection: the size of fuel droplets, the dispersity and, as a result, period of induction $\varphi_{i}$ and kinetic phase of combustion.

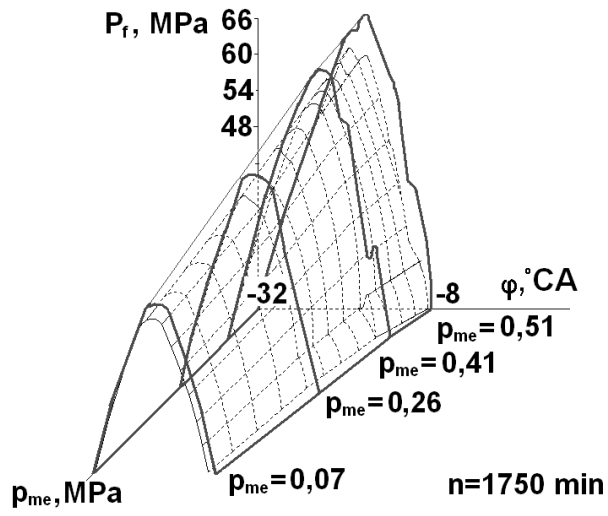

Fig 9. The characteristic of fuel injection $P_{f}$ of diesel engine A41: - RME biodiesel B100, - - _ , diesel fuel

The law of fuel injection in differential and integral $\bar{g}=f(x)$ forms can be reasonably estimated depending on experimentally determined characteristic $P_{f}=f(\varphi)$ :

$$
\frac{d g}{d \varphi}=\mu_{p} f_{p} \sqrt{2 \rho} \frac{P_{f}-P_{c i l}}{\sqrt{\left|P_{f}-P_{c i l}\right|}} \times \frac{1}{G n_{s}},
$$

where $P_{c i l}$ - in-cylinder pressure, $G$ - cycle portion of fuel, $n_{s}$ - revolutions of fuel pump crankshaft, $\mu_{p}, f_{p}-$ effective square of holes of injector.

Experimentally obtained and manually treated characteristics $\bar{g}=f(\varphi)$ at corresponding values of indicated pressure $p_{m i}$ shows that the law of fuel injection remains the same when replacing the mineral diesel fuel by biodiesel. The above data made available to state that the critical deviations of macro factors of fuel injection are not determined for the replacement of mineral diesel fuel by biodiesel up to pure biodiesel B100, and extra regulation of fuel supply system is not required.

The torch of biodiesel is characterised by worse micro factors of injection - dispersity of injection because of higher values of density $\rho$, viscosity $v$ and forces of surface tension $\sigma$ of biodiesel [8]. The ratio of sizes of biodiesel and mineral diesel fuel droplets evalting by Zauter diameter [9] is determined by formula:

$$
\frac{D_{32}^{\text {Bio }}}{D_{32}^{D}}=\left(\frac{\rho^{\text {Bio }}}{\rho^{D}}\right)^{0,0733} \times\left(\frac{v^{\text {Bio }}}{v^{D}}\right)^{0,1465} \times\left(\frac{\sigma^{\text {Bio }}}{\sigma^{D}}\right)^{0,193}
$$

The influence of parameters $\rho, v$ and $\sigma$ on diameter $D_{32}$ of droplets of torch is estimated by index of degree. It is obvious, $D_{32}$ is mostly influenced by viscosity $v$ and forces of surface tension $\sigma$. The force of surface tension $\sigma^{\text {Bio }}$ of biodiesel is higher approximately by $10 \%$, the value of viscosity of biodiesel is two times higher and thus predetermine the biggest influence on $D_{32}$. The waited overall increase of $D_{32}$ is $17 \%$ for biodiesel B100.

\subsection{The characteristics of heat release}

The characteristics of evaporation of biodiesel is as worse as dispersity: temperature at the start of evaporation of RME $-299^{\circ} \mathrm{C}$, when the same of mineral diesel fuel $-178^{\circ} \mathrm{C}$ and higher value of specific enthalpy of evaporation. The influence of working fluid of biodiesel on work process is evaluated by characteristics of heat release $X, d X / d \varphi=f(\varphi)$ (see Figs 10,11 ). The analysis of characteristics of heat release is accented on the first - kinetic $\left(d X_{I} / d \varphi\right)_{\max }$ and the second - diffusion $\left(d X_{I I} / d \varphi\right)_{\max }$ maximums of speed of heat release.

$\left(d X_{I} / d \varphi\right)_{\max }$ forms the dynamic parameters of work process: ratio of pressure speed $(d p / d \varphi)_{\max }$, pressure ratio $\lambda$, maximum pressure of cycle $p_{\max }$ and emission of nitric oxides $\mathrm{NO}_{\mathrm{x}}$. The character of fuel combustion in the second - diffusion phase influences parameters of fuel economy and emission of products of noncomplete combustion: (carbon monoxide $\mathrm{CO}$, hydrocarbons $\mathrm{CH}$ and smoke).

The reduction of induction period $\varphi_{i}$ for the biodiesel $\mathrm{B} 30$ and $\mathrm{B} 100$ is determined by $1^{\circ} \mathrm{CA}$ and $2^{\circ} \mathrm{CA}$ (see Fig 6). The values of cetane number of biodiesels B30 and $\mathrm{B} 100$ are 50 and 57 being compared to the same of mineral diesel fuel -46 . The quantity of fuel injected per cycle reduces together with the reduction of induction period $\varphi_{i}$, because the start of injection and the law of injection remain constant. The observed reduction of $\left(d X_{I} / d \varphi\right)_{\max }$ (see Fig 10) is related to lower quantity of injected and prepared for combustion fuel (because of worse characteristics of evaporation) at the time of induction period. The significant reduction of $(d X / d \varphi)_{\max }$ is observed at regime of nominal load: $\left(d X_{\nu} / d \varphi\right)_{\max }$ reduces approximately by $30 \%$ from $0,09{ }^{\circ} \mathrm{CA}^{-1}$ down to $0,06^{\circ} \mathrm{CA}^{-1}$ medium indicated pressure $p_{m i}=0,4 \div 0,5 \mathrm{MPa}$. 


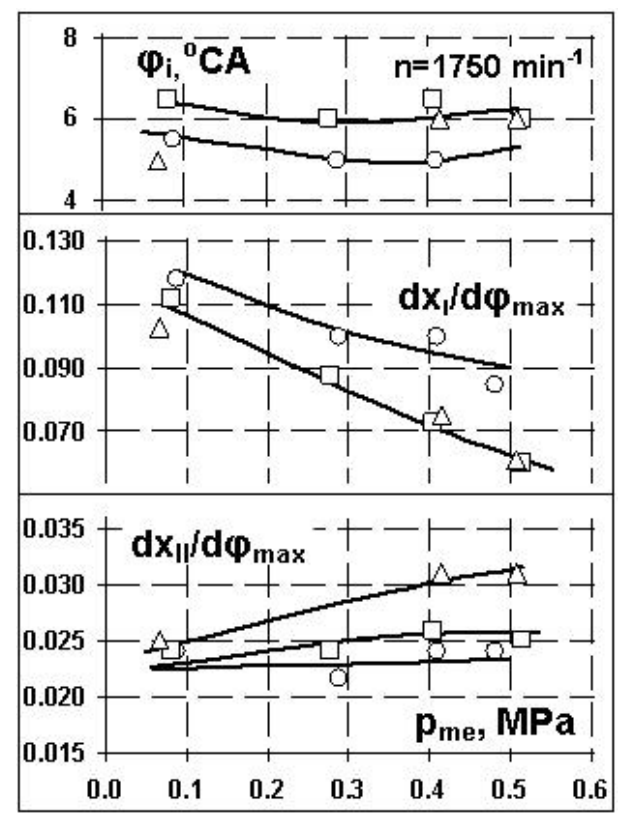

Fig 10. The parameters of heat release of diesel engine A41 while running on biodiesel: $\bigcirc$ - diesel fuel, $\square-$ RME biodiesel B30, $\triangle-$ RME biodiesel B100

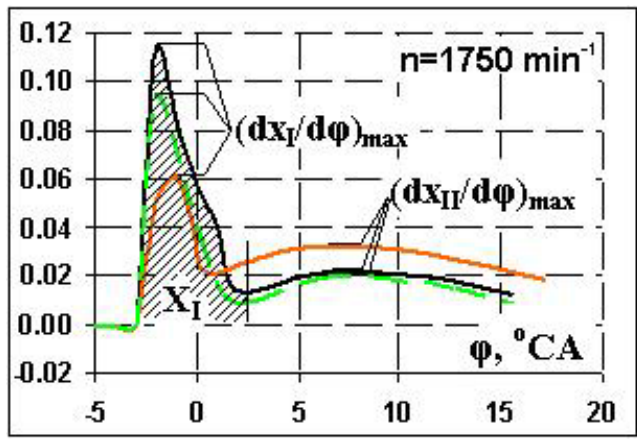

Fig 11. The change of characteristics of heat release $\left(\mathrm{dX}_{\mathrm{I}} / \mathrm{d} \varphi\right)_{\max }$ and $\left(\mathrm{dX}_{\mathrm{II}} / \mathrm{d} \varphi\right)_{\max }$ of diesel engine A41 while running on biodiesel: _ - diesel fuel, - - - - - RME biodiesel B30, $\_$RME biodiesel B100

As a result, the dynamic parameters of load reduce: ratio of pressure speed $(d p / d \varphi)_{\max }$ reduces from $0,9 \mathrm{MPa} /{ }^{\circ} \mathrm{CA}$ down to $0,85 \mathrm{MPa} /{ }^{\circ} \mathrm{CA}$ for biodiesle B30 and down to $0,7 \mathrm{MPa} /{ }^{\circ} \mathrm{CA}$ for biodiesle B100 at the regime of load $p_{m i}=0,73 \div 0,83 \mathrm{MPa}$.

The criterions of mechanical load of parts of cylinder-liner group $p_{\max }$ and pressure ratio $\lambda$ depend mainly on heat quantity $Q_{P \max }$ released until the moment the maximum cycle pressure is reached at the identical conditions. The identical level of $Q_{P \max } \approx$ idem is determined for all tested sorts of fuels. The said above confirms the constancy of experimentally determined parmeters $p_{\max }, \lambda \approx \mathrm{idem}$. The mentioned fact is related to the increase of speed of heat release in the second diffusion phase of combustion when running on biodiesel.

The heat release in the second phase of combustion increases by increasing the load $p_{m e}\left(p_{m i}\right)$ when running on biodiesel. The increase of quantity of biocomponent in RME biodiesel approximatelly equally increases $\left(d X_{I I} / d \varphi\right)_{\max }$ (see Fig 11). The dependence of parameter $\left(d X_{I I} / d \varphi\right)_{\max }$ on load is significant being compared to the same of mineral diesel fuel: $\left(d X_{I I} / d \varphi\right)_{\max }$ increases from $0,023 \mathrm{CA}^{-1}$ at low load up to $0,026 \mathrm{CA}^{-1}$ at load regime $p_{m e}=0,5 \mathrm{MPa}$. The replacement of mineral diesel fuel by biodiesel $\mathrm{B} 100$ increases $\left(d X_{I I} / d \varphi\right)_{\max }$ up to $0,031 \mathrm{CA}^{-1}$ that is by $\sim 35 \%$ higher being compared to the same of mineral diesel fuel.

The increase of $\left(d X_{I I} / d \varphi\right)_{\max }$ predetermines increase of indicated efficiency factor $\eta_{i}$ at running of diesel engine on biodiesel. The intensification of diffusion phase of combustion also reduces the emission of noncomplete combustion ( $\mathrm{CO}, \mathrm{CH}$ and smoke), which is a characteristic feature of biodiesel. The mostly believable reason for intensification of diffusion phase of combustion is the higher concentration of oxygen in the biodiesel: $10 \%$ being compared to the same of diesel engine $\sim 1 \%$. The oxygen presented in the composition of biodiesel takes part in combustion increasing at the same time overall and local air ratios and thus becomes the reason for intensification of combustion.

The results of experimental researches confirm the positive influence of biodiesel on all main described above work parameters of diesel engine: the increase of indicated efficiency factor $\eta_{i}$, the constancy of mechanical and thermal load of parts of cylinder-liner group, the reduction of emission of products of non-complete combustion ( $\mathrm{CO}, \mathrm{CH}$ and smoke).

\section{Conclusions}

The new data on dynamics of biodiesel combustion was obtained by complex researches into characteristics of fuel injection and indicated work of diesel engine 1A41. The results of researches had allowed to substantiate the conformity with the law of change of main operational parameters of diesel engine while running on biodiesel fuel. The following principal propositions for replacement of mineral diesel fuel by biodiesel in operating fleets of diesel engines of Lithuania were formulated:

1. The law and phases of fuel injection of RME biodiesel and biodiesel B100 as well remain constant being compared to mineral diesel fuel. The increase of maximum injection pressure by $5 \%$ for biodiesel B30 and by $10 \%$ for B100 stabilises characteristics of injection.

2. The reduction of induction period by $\sim 15 \%$ while running on biodiesel (B30 and B100 respectively by 1 and $2{ }^{\circ} \mathrm{CA}$ ) influences the reduction of heat release in kinetic phase $(d X / d \varphi)^{I}{ }_{\max }$ by $\sim 30 \%$. It also reduces the mechanical load of parts of cylinder-liner group: ratio of pressure speed $(d p / d \varphi)_{\max }$ reduces from $0,9 \mathrm{MPa} /{ }^{\circ} \mathrm{CA}$ down to $0,85 \mathrm{MPa} /{ }^{\circ} \mathrm{CA}$ for biodiesel B30 and down to $0,7 \mathrm{MPa} /{ }^{\circ} \mathrm{CA}$ for biodiesel $\mathrm{B} 100$ at the regime of load $p_{m i}=0,73 \div 0,83 \mathrm{MPa}$.

3 . The increase of heat release at diffusion phase of combustion $(d X / d \varphi)^{I I}{ }_{\text {max }}$ by $\sim 55 \%$ (from $0,023 \mathrm{CA}^{-1}$ at low load up to $0,026 \mathrm{CA}^{-1}$ at load regime $p_{m e}=0,5 \mathrm{MPa}$ for biodiesel $\mathrm{B} 30$ and up to $0,031^{\circ} \mathrm{CA}$ for $\mathrm{B} 100$ ) positi- 
vely influences the increase of indicated efficiency factor $\eta_{i}$ by $\sim 2 \%$ and partly compensates the increase of fuel consumption because of lower heat value of biodiesel being compared to mineral diesel fuel.

4. The reduction of intensiveness of heat release $(d X / d \varphi)^{I}{ }_{\text {max }}$ in kinetic phase of combustion and the increase of intensiveness of heat release $(d X / d \varphi)^{I I}{ }_{\max }$ in diffusion phase of combustion at the same time predetermines the constancy of heat quantity $Q_{P \max }$ released untill the moment the maximum cycle pressure is reached. As a result, the running of diesel engine on biodiesel does not increase maximum in-cylinder pressure $p_{\max }$ and characteristic temperatures of gases which forms mechanical and thermal load of parts of cylinderliner group.

5. The determined interrelations of parameters of indicated work allow to state the following directions of modification of mathematical modelling programs for adapting them for the research of biodiesel:

- the correction of criterional and multifunctional dependences such as $\eta_{i}=f\left(\alpha, \lambda, p_{k}, \varepsilon, T_{k}\right)$ by entering simplexes for discovering properties of biodiesels;

- the formation of analytic formulas of characteristics of heat release $X, d X / d \varphi=f(\varphi)$ for biodiesels and of dependence on main parameters of work process and work regime as well.

6. The achieved constant temperature of exhaust gases $T_{g}$ while running of diesel engine on biodiesel at the constant rated load $P_{e}=$ idem for all sorts of tested fuels allows to forecast qualitative similar change of main operational parameters of turbocharged diesel engines as well.

Presumptions of effective operation of diesel engines running on RME biodiesel:

1. Concentration of biodiesel fuel up to and equal to $30 \%$ in mixture with mineral diesel fuel is optimal to be used practically in respect of fuel saving change and effect of the improvement of ecological parameters. Specific fuel consumption deterioration and thrust characteristics decrease were as follows: for B30 biodiesel fuel $-2 \div 3 \%$ at the constant load. Ecological parameters were changed as follows: $\mathrm{CO}-30 \div 37 \%, \mathrm{CH}$ $20 \div 50 \%$, smoke emission $\sim 50 \div 55 \%$ while increase of nitric oxides $\mathrm{NO}_{\mathrm{x}}$ emission was appropriately $10 \div 12 \%$.

2. The running of diesel engine on biodiesel and biodiesel B100 as well does not require extra regulation of fuel supply system: neither maximum portion of the cycle nor the static fuel injection timing.

3. Allowable by technical regulations of maintenance the reduction of fuel injection timing by $2^{\circ}$ of crank angle makes available to obtain complex reduction of all harmful emission parameters including nitric oxides $\left(\mathrm{NO}_{\mathrm{x}}\right)$ while running on biodiesel fuel, i.e. rapeseed methyl esters.

4. The running of diesel engine on biodiesel and biodiesel B100 as well does not increase thermal and mechanical load of parts of cylinder-liner group and does not deteriorate the parameters of reliability.

\section{References}

1. SRIVASTAVA, A.; PRASSAD, R. Triglicerides-based diesel fuels. In Renewable and Sustainable Energy Reviews, 2000, p. 111 - 133.

2. WOSCHNI, G. Die Berechnung der Wandverluste und der thermischen Belastung der Bauteile von Dieselmotoren. MTZ, 1970, Bd. 12, p. 491-499.

3. MOLODCOV, N.; SOKOLOV, P.; VLASOV, Y. The influence of constructive-regulational parameters and ratio of boosting on ratio of heat transference from exhaust gases into surface of parts of cylinder-liner group (Влияние конструктивно-регулировочных показателей и степени форсирования на коэффициент теплоотдачи от газов к поверхности деталей ЦПГ). In Works of Central Scientific Institute of Diesel Engines, St. Petersburg, 1975. 65 p. (in Russian).

4. VUKALOVICH, M.; KIRILIN, V.; REMIZOV, S. Thermodinamycal properties of gases (Термодинамические свойства газов). Moscow: 1953. 376 р. (in Russian).

5. LEBEDEVAS, S. Reduction of $\mathrm{NO}_{\mathrm{x}}$ emission in exhaust gases of diesel engines by applying the motor methods. Transportas (Transport Engineering), Vilnius: Technika, 2001, Vol XVI, No 4, p. 32-43.

6. SMAILYS, V.; BYKOV, V. Optimization of economical and ecological parameters of diesel ChN21/21 boosting it by rated break mean effective pressure. Engineering (Двигателестроение), 1990, № 4, p. 44-46 (in Russian).

7. LEBEDEVAS, S.; VAICEKAUSKAS, A.; LEBEDEVA, G.; KULMANAKOV, S.; SASHEV, S. The change of operational characteristics of diesel engines running on RME biodiesel. Parameters of thrust and fuel economy. In Transport means 2006, Proceedings of the $10^{\text {th }}$ International Conference. Kaunas, 2006, p. 229-233. ISSN 1822296-X.

8. LYSHEVSKIJ, A. Suply systems of diesel engine (Системы питания дизелей). Moscow: Mashinostrojenie, 1981. 216 p. (in Russian).

9. GRABOSKI, M. S.; MCCORMICK, R. L. Combustion of fat and vegetable oil derived fuels in diesel engines. In Progress in Energy and Combustion Science, 1998, Vol 24, p. 125-164. 